2 Eyster ME, Gail MH, Ballard JO, et al. Natural history of immunodeficiency virus infections in hemophiliacs: effects of $\mathrm{T}$ cell subsets, platelet counts and age. Ann Intern Med 1987;107:1-11.

3 Lee CA, Phillips A, Elford J, et al. The natural history of human immunodeficiency virus infection in a haemophilic cohort. Br f Haematol 1989;73: 228-34.

4 Polk BF, Fox R, Brookmeyer R, et al. Predictors of the acquired immunodeficiency syndrome developing in a cohort of seropositive homosexual men. N Engl f Med 1987;316:61-6.

5 Moss AR, Bacchetti P, Osmond D, et al. Seropositivity for HIV and the development of AIDS or AIDS related condition: three year follow up of the San Francisco General Hospital cohort. Br Med f 1988;296:745-50.

6 Munoz A, Carey V, Saah AJ, et al. Predictors of decline in CD4 lymphocytes in a cohort of homosexual men infected with human immunodeficiency virus. Fournal of the Acquired Immunodeficiency Syndrome 1988;1:396-404.

7 Pedersen C, Kolby P, Sindrup J, et al. The development of AIDS or AIDSrelated conditions in a cohort of HIV antibody-positive homosexual men during a 3 year follow-up period. Foumal of Internal Medicine 1989;225: 403-9.

8 Lefrere JJ, Lambin P, Courouce AM, Doinel C. Progression to AIDS in the majority of asymptomatic HIV-infected people. AIDS 1989;3:603-4.

9 Fuchs D, Hansen A, Reibnegger G, et al. Neopterin as a marker for activated cell-mediated immunity: application in HIV infection. Immunology Today cell-mediated

10 Sears SD, Fox R, Brookmeyer R, et al. Delayed hypersensitivity skin testing and anergy in a population of gay men. Immunopathology 1987;45:177-83.

1 Brettler DB, Forsberg AD, Brewster AD. Delayed cutaneous hypersensitivity reactions in hemophiliac subjects treated with factor concentrate. $\mathrm{Am} \mathcal{F} \mathrm{Med}$ 1986;81:607-11
12 Ludlam CA, Tucker J, Steel CM, et al. Human T lymphotropic virus type III HTLV-III) infection in seronegative haemophiliacs after transfusion with factor VIII. Lancet 1985; ;i:233-6.

13 Simmonds P, Lainson FAC, Cuthbert RJG, et al. HIV antigen and antibody detection: variable responses to infection in the Edinburgh haemophiliac cohort. Br Med F 1988;296:593-8.

14 Cuthbert RJG, Ludlam CA, Rebus $S$, et al. Human immunodeficiency virus detection: correlation with clinical progression in the Edinburgh haemophiliac cohort. Brf Haematol 1989;72:387-90.

15 Mildvan D, Solomon SL. The spectrum of disease due to human immunodeficiency virus. Current Topics in AIDS 1987;1:31-55.

16 Carr R, Edmund E, Prescott RJ, et al. Abnormalities of circulating T cell subsets in haemophiliacs in an AIDS-free population. Lancet 1984; $1431-74$

17 Jin Z, Cleveland RP, Kaufman DB. Immunodeficiency in patients with hemophilia: an underlying deficiency and lack of correlation with factor replacement therapy or exposure to human immunodeficiency virus. f Allergy Clin Immunol 1989;83:165-70.

18 Steel CM, Beatson D, Cuthbert RJG, et al. HLA haplotype A1 B8 DR3 as a risk factor for HIV-related disease. Lancet 1988;i:1185-8.

19 Kaslow RA, Duquesnoy R, Van Raden M, et al. Al, Cw7, B8, DR3 HLA antigen combination associated with rapid decline of $\mathrm{T}$-helper lymphocytes in HIV-1 infection. Lancet 1990;335:927-30.

20 Mallal S, Cameron PU, French MAH, Dawkins RL. MHC genes and HIV infection. Lancet 1990;335:1591-2.

21 Anonymous. Clinical trials of zidovidine in HIV infection [Editorial]. Lancet 1989;ii:483-4.

(Accepted 25 fuly 1990)

\title{
Effects of discrimination by sex and race on the early careers of British medical graduates during 1981-7
}

\author{
P M McKeigue, J D M Richards, P Richards
}

\section{Abstract}

Objective-To examine the possible effects of discrimination by sex and race on the career patterns of doctors up to six years after qualifying.

Design-Postal questionnaire follow up survey.

Participants - 1572 Doctors who graduated from five British medical schools in 1981, 1983, and 1985, including 587 women and 131 doctors from ethnic minorities.

Main outcome measures-Reported success rates of applications for training posts.

Results-Comparison of the career patterns of women and men yielded no evidence of discrimination against women in competition for posts. In contrast, there were striking differences in career patterns between graduates of native European origin and those of ethnic minority origin. Graduates from ethnic minorities reported lower success rates and more difficulty in obtaining house officer posts, registrar posts, and places in vocational training schemes in general practice. Most of this discrimination seemed to occur at the stage of shortlisting for interview. Graduates from ethnic minorities were more likely than graduates of native European origin to have experienced spells of unemployment while seeking work. They were also more likely to have changed their original choice of career because of difficulty in obtaining suitable training posts or unfavourable career prospects.

Conclusions-Discrimination against ethnic minorities occurs in the competition for training posts among graduates from British medical schools. There was no evidence of discrimination against women graduates. Shortlisting procedures based on objective scoring systems may help to ensure equality of opportunity in future.

\section{Introduction}

Several lines of evidence suggest that discrimination against women and ethnic minorities occurs in British medicine. ${ }^{12}$ Systematic discrimination has been recorded in the admissions procedure of at least one medical school, ${ }^{3}$ and analysis of the proportions of students at other medical schools who had nonEuropean names suggests that this was not an isolated instance. ${ }^{1}$ The only available data on the career patterns of British trained doctors from ethnic minorities are from a survey of hospital doctors in two northern regions in $1980 .{ }^{4}$ The results suggested that doctors from ethnic minorities, whether trained in Britain or overseas, were experiencing disproportionate difficulty in obtaining hospital posts compared with their native European counterparts. The survey, however, was not based on a representative sample of medical graduates, and the number of British trained doctors from ethnic minorities was very small. In 1987 the University Hospitals Association decided to undertake a survey of the careers of recent medical graduates to examine the problems experienced by this group in obtaining suitable training posts and pursuing their chosen careers. ${ }^{5}$ We examined this dataset for evidence of discrimination by sex and race.

\section{Methods}

Five medical schools were chosen to make up a geographically representative sample. Questionnaires were sent during 1987 to all 2002 medical graduates who qualified during 1981,1983 , and 1985 at these five medical schools accompanied by a covering letter from the dean of each graduate's medical school. To maintain confidentiality questionnaires were identified only by serial number. Linkage to names and addresses was used only to identify non-respondents, who were sent a reminder letter. A total of 1572 replies were received, giving a response rate of $79 \%$.

The questionnaire included items on demographic background, career choice, and intended postgraduate qualifications at the time of completing the preregistration year; numbers of unsuccessful applications submitted before obtaining each senior house officer and registrar post; numbers of interviews for each post without the offer of a job; and present career choice. Those who had changed their first choice of career since completing the preregistration year were asked to 
rate as important or unimportant each of seven possible reasons (listed in table $\mathrm{X}$ ). Respondents were also asked to indicate their ethnic origin as either AfroCaribbean, Chinese, European, Indian subcontinent, or other. Based on their answers they were categorised as native European and ethnic minority. Participants were invited to add comments on their experiences on the back of the questionnaire. Participants' career choices at the time they completed their preregistration posts were grouped into three categories based on advice from the Medical Manpower Division of the Department of Health (J C Dobson, personal communication)-namely, undersubscribed specialties (anaesthetics, community medicine, ophthalmology, otolaryngology, clinical pathology, geriatrics, psy-

TABLE I-Initial career choice category by sex and ethnic group. Figures are percentages (whole numbers in parentheses)

\begin{tabular}{|c|c|c|c|c|}
\hline & $\underset{(\mathrm{n}=888)}{\text { Men }}$ & $\begin{array}{c}\text { Women } \\
(\mathrm{n}=520)\end{array}$ & $\begin{array}{c}\text { Native } \\
\text { European } \\
(n=1247)\end{array}$ & $\begin{array}{l}\text { Ethnic } \\
\text { minority } \\
(n=124)\end{array}$ \\
\hline Undersubscribed & $19(165)$ & $20(102)$ & $19(241)$ & $19(23)$ \\
\hline Oversubscribed & $43(379)$ & $27(142)$ & $37(457)$ & $40(49)$ \\
\hline General practice & $39(344)$ & $53(276)$ & $44(549)$ & $42(52)$ \\
\hline $\mathrm{p}$ Value & \multicolumn{2}{|c|}{$<0.001$} & \multicolumn{2}{|c|}{ NS } \\
\hline
\end{tabular}

TABLE II-Percentages of men and women graduates who had to wait less than one month to over two months before securing first senior house officer post (whole numbers in parentheses)

\begin{tabular}{|c|c|c|c|c|}
\hline & \multicolumn{3}{|c|}{ Wait (months) } & \multirow[b]{2}{*}{ p Value ${ }^{\star}$} \\
\hline & $<1$ & $1-2$ & $>2$ & \\
\hline $\begin{array}{l}\text { Men }(n=970) \\
\text { Women }(n=575)\end{array}$ & $\begin{array}{l}86(839) \\
90(518)\end{array}$ & $\begin{array}{l}7(65) \\
5(27)\end{array}$ & $\begin{array}{l}7(66) \\
5(30)\end{array}$ & NS \\
\hline
\end{tabular}

^Significance calculated after stratifying by career choice category.

TABLE III-Percentages of men and women graduates who made up to five, six to nine, and 10 or more unsuccessful applications for each post (whole numbers in parentheses)

\begin{tabular}{|c|c|c|c|c|c|}
\hline & & \multicolumn{3}{|c|}{ No of unsuccessful applications } & \multirow[b]{2}{*}{ p Value ${ }^{\star}$} \\
\hline & & $\leqslant 5$ & $6-9$ & $\geqslant 10$ & \\
\hline First senior house officer post & $\left\{\begin{array}{l}\operatorname{Men}(\mathbf{n}=962) \\
\text { Women }(n=576)\end{array}\right.$ & $\begin{array}{l}73(698) \\
76(438)\end{array}$ & $\begin{array}{l}11(107) \\
12(68)\end{array}$ & $\begin{array}{l}16(157) \\
12(70)\end{array}$ & NS \\
\hline Second senior house officer post & $\left\{\begin{array}{l}\text { Men }(n=715) \\
\text { Women }(n=418)\end{array}\right.$ & $\begin{array}{l}84(601) \\
87(365)\end{array}$ & $\begin{array}{ll}8 & (55) \\
7 & (31)\end{array}$ & $\begin{array}{ll}8 & (59) \\
5 & (22)\end{array}$ & NS \\
\hline Third senior house officer post & $\left\{\begin{array}{l}\operatorname{Men}(n=453) \\
\text { Women }(n=271)\end{array}\right.$ & $\begin{array}{l}86(389) \\
89(241)\end{array}$ & $\begin{array}{ll}6 & (28) \\
6 & (17)\end{array}$ & $\begin{array}{ll}8 & (36) \\
5 & (13)\end{array}$ & 0.03 \\
\hline Fourth senior house officer post & $\left\{\begin{array}{l}\operatorname{Men}(\mathbf{n}=309) \\
\text { Women }(n=211)\end{array}\right.$ & $\begin{array}{l}92(283) \\
93(197)\end{array}$ & $\begin{array}{ll}5 & (14) \\
5 & (10)\end{array}$ & $\begin{array}{rr}4 & (12) \\
2 & (4)\end{array}$ & NS \\
\hline Fifth senior house officer post & $\left\{\begin{array}{l}\operatorname{Men}(n=176) \\
\text { Women }(n=120)\end{array}\right.$ & $\begin{array}{l}89(157) \\
95(114)\end{array}$ & $\begin{array}{ll}5 & (9) \\
3 & (4)\end{array}$ & $\begin{array}{rr}6 & (10) \\
2 & (2)\end{array}$ & NS \\
\hline First registrar post & $\left\{\begin{array}{l}\text { Men }(n=270) \\
\text { Women }(n=96)\end{array}\right.$ & $\begin{array}{l}95(256) \\
99(95)\end{array}$ & $\begin{array}{ll}3 & (7) \\
1 & (1)\end{array}$ & $\begin{array}{ll}3 & (7) \\
0 & (0)\end{array}$ & 0.03 \\
\hline
\end{tabular}

* Significance calculated after stratifying by career choice category.

TABLE IV - Percentages of men and women graduates who did and did not report serious difficulty in obtaining appropriate registrar posts (whole numbers in parentheses)

\begin{tabular}{lrcc}
\hline & Yes & No & p Value $^{\star}$ \\
\hline Men $(\mathbf{n}=285)$ & $\begin{aligned} 13(36) \\
6(6)\end{aligned}$ & $\begin{array}{l}87(249) \\
\text { Women }(\mathbf{n}=104)\end{array}$ & NS \\
\hline
\end{tabular}

« Significance calculated after stratifying by career choice category.

TABLE $\mathrm{v}$-Percentages of native European and ethnic minority graduates who had to wait less than one month to over two months before securing first senior house officer post (whole numbers in parentheses)

\begin{tabular}{lcccc}
\hline & \multicolumn{3}{c}{ Wait (months) } & \\
\cline { 2 - 4 } & $<1$ & $1-2$ & $>2$ & p Value \\
\hline Native European $(\mathrm{n}=1375)$ & $88(1215)$ & $6(85)$ & $5(75)$ & $($ a $) 0 \cdot 01,(b) 0.02$ \\
Ethnic minority $(\mathrm{n}=130)$ & $84(109)$ & $3(4)$ & $13(17)$ & \\
\hline
\end{tabular}

^Significance calculated $(a)$ unstratified, $(b)$ after controlling for sex. chiatry, radiology); oversubscribed specialties (internal medicine, paediatrics, surgery (but excluding ophthalmology and otolaryngology), obstetrics, gynaecology); and general practice.

The grouping used in the tables of numbers of applications (tables III and VI), numbers of interviews (table IX), and time waiting for posts (tables II and V) is the same as in the original questionnaire. Tests of significance were based on the generalised CochranMantel-Haenszel $\chi^{2}$ statistic, ${ }^{6}$ testing for trend with ordered categories. To control for the lower proportion of women than men who chose oversubscribed specialties the data were stratified by career choice category when testing for sex differences in the success rate of applications for hospital posts. The same technique was used to control for sex when testing for ethnic differences in career patterns. Fisher's exact test was used for unstratified $2 \times 2$ tables when the expected number in any cell was less than five.

\section{Results}

Of the 1572 respondents, 985 (63\%) were men and 587 women. For comparison the records of the five participating medical schools were examined to determine the sex ratio among those graduating in 1983. A total of $418(61 \%)$ of the 680 graduates were men. Altogether 1398 respondents were of native European origin and 131 ethnic minority origin. Forty three respondents omitted the question on ethnic origin. As all but two of these 43 respondents were born in the United Kingdom it is unlikely that this group contained many graduates from ethnic minorities; examination of the records suggested that most were native British graduates who did not realise that the question on ethnic origin applied to them. Ninety six $(73 \%)$ of the respondents from ethnic minorities were born outside the United Kingdom; south Asians were the largest group. The proportion of women was 25\% (33 of 131) among respondents from ethnic minorities and 38\% (538 of 1398) among native European respondents $(\mathrm{p}<0.01)$.

A total of 146 of 581 (25\%) women graduates and 55 of $131(42 \%)$ graduates from ethnic minorities considered that they had been subjected to discrimination on account of their sex and ethnic origin. Comparison of the initial career choices of men and women showed that women were less likely to choose oversubscribed specialties and more likely to choose general practice (table I). Examination of career patterns did not yield any evidence of discrimination against women in the competition for posts at this stage. Women reported slightly less difficulty than men in obtaining senior house officer and registrar posts (tables II-IV). After stratifying by career choice category only two of seven comparisons between the success rates of men and women differed at the $5 \%$ level of significance (tables II-IV).

Eighteen of $130(14 \%)$ graduates from ethnic minorities reported difficulty in obtaining preregistration posts compared with 110 of $1388(8 \%)$ graduates of native European origin $(p=0.02)$. There were no significant differences between native Europeans and people from ethnic minorities in the proportions choosing careers in undersubscribed and oversubscribed specialties (table I). Thirteen per cent (17/130) of graduates from ethnic minorities had to wait more than two months for their first senior house officer post compared with 5\% (75/1375) of native European graduates (table V). The numbers of unsuccessful job applications submitted before obtaining each senior house officer post and the first registrar post were substantially higher among graduates from ethnic minorities than among native Europeans (table VI). The numbers of respondents who had applied for posts 


\begin{tabular}{|c|c|c|c|c|c|}
\hline & & \multicolumn{3}{|c|}{ No of unsuccessful applications } & \multirow[b]{2}{*}{ p Value } \\
\hline & & $\leqslant 5$ & $6-9$ & $\geqslant 10$ & \\
\hline First senior house officer post & $\left\{\begin{array}{l}\text { Native European }(n=1368) \\
\text { Ethnic minority }(n=130)\end{array}\right.$ & $\begin{array}{l}75(1029) \\
60 \quad(78)\end{array}$ & $\begin{array}{l}11(146) \\
18(23)\end{array}$ & $\begin{array}{l}14(193) \\
22(29)\end{array}$ & (a) $0.001,(b) 0.001$ \\
\hline Second senior house officer post & $\left\{\begin{array}{l}\text { Native European }(n=1017) \\
\text { Ethnic minority }(n=88)\end{array}\right.$ & $\begin{array}{lr}86 & (876) \\
70 & (62)\end{array}$ & $\begin{aligned} 7 & (72) \\
16 & (14)\end{aligned}$ & $\begin{aligned} 7 & (69) \\
14 & (12)\end{aligned}$ & $(a)<0.001,(b) 0.001$ \\
\hline Third senior house officer post & $\left\{\begin{array}{l}\text { Native European }(n=652) \\
\text { Ethnic minority }(n=53)\end{array}\right.$ & $\begin{array}{rr}87 & (570) \\
81 & (43)\end{array}$ & $\begin{array}{lr}6 & (39) \\
8 & (4)\end{array}$ & $\begin{array}{rr}7 & (43) \\
11 & (6)\end{array}$ & (a) NS, $(b)$ NS \\
\hline Fourth senior house officer post & $\left\{\begin{array}{l}\text { Native European }(n=473) \\
\text { Ethnic minority }(n=32)\end{array}\right.$ & $\begin{array}{rr}93 & (439) \\
81 & (26)\end{array}$ & $\begin{array}{rr}5 & (22) \\
6 & (2)\end{array}$ & $\begin{array}{rr}3 & (12) \\
13 & (4)\end{array}$ & (a) $0.003,(b) 0.007$ \\
\hline Fifth senior house officer post & $\left\{\begin{array}{l}\text { Native European }(n=267) \\
\text { Ethnic minority }(n=21)\end{array}\right.$ & $\begin{array}{lr}93 & (247) \\
76 & (16)\end{array}$ & $\begin{array}{rr}4 & (12) \\
5 & (1)\end{array}$ & $\begin{array}{rr}3 & (8) \\
19 & (4)\end{array}$ & (a) $0.001,(b) 0.004$ \\
\hline First registrar post & $\left\{\begin{array}{l}\text { Native European }(n=332) \\
\text { Ethnic minority }(n=21)\end{array}\right.$ & $\begin{array}{rr}97 & (322) \\
81 & (17)\end{array}$ & $\begin{array}{rr}1 & (4) \\
14 & (3)\end{array}$ & $\begin{array}{ll}2 & (6) \\
5 & (1)\end{array}$ & (a) $0.006,(b) 0.008$ \\
\hline
\end{tabular}

* Significance calculated $(a)$ unstratified, $(b)$ after controlling for sex.

after these stages were too small to analyse. Tables VII and VIII give the proportions of native European graduates and graduates from ethnic minorities who reported serious difficulty in obtaining an appropriate registrar post and who spent less than one month to over four months seeking work since qualifying. Controlling for sex did not lessen the significance of the differences between graduates from ethnic minorities and native Europeans. Despite the striking differences in numbers of unsuccessful job applications, there were no consistent differences between graduates of native European origin and those from ethnic minorities in the numbers of unsuccessful interviews reported (table IX). The data on success rates at interview, however, were based on very small numbers after the second senior house officer post.

Half of the graduates in each group had applied for a place in a vocational training scheme in general practice. Only 33 of 65 graduates $(51 \%)$ from ethnic minorities who applied had been successful compared

TABLE VII-Percentages of native European and ethnic minority graduates who did and did not report serious difficulty in obtaining appropriate registrar post (whole numbers in parentheses)

\begin{tabular}{lccc}
\hline & Yes & No & p Value $^{\star}$ \\
\hline Native European $(\mathrm{n}=352)$ & $10(36)$ & $90(316)$ & $($ a $) \mathrm{NS},(b) \mathrm{NS}$ \\
Ethnic minority $(\mathrm{n}=24)$ & $21(5)$ & $79(19)$ & \\
\hline
\end{tabular}

* Significance calculated $(a)$ unstratified, $(b)$ after controlling for sex.

TABLE VIII - Percentages of native European and ethnic minority graduates who spent less than one month to over four months unemployed and seeking work since qualifying (whole numbers in parentheses)

\begin{tabular}{|c|c|c|c|c|}
\hline & \multicolumn{3}{|c|}{ Time unemployed (months) } & \multirow[b]{2}{*}{ p Value ${ }^{\star}$} \\
\hline & $<1$ & $1-3$ & $\geqslant 4$ & \\
\hline $\begin{array}{l}\text { Native European }(n=1396) \\
\text { Ethnic minority }(n=131)\end{array}$ & $\begin{array}{l}92(1283) \\
82(108)\end{array}$ & $\begin{array}{r}6(78) \\
10(13)\end{array}$ & $\begin{array}{l}3(35) \\
8(10)\end{array}$ & $(a)<0.001,(b)<0.001$ \\
\hline
\end{tabular}

$\star$ Significance calculated $(a)$ unstratified, $(b)$ after controlling for sex.

TABLE IX - Percentages of native European and ethnic minority graduates who reported up to three and four or more unsuccessful interviews for each post (whole numbers in parentheses)

\begin{tabular}{|c|c|c|c|c|}
\hline & & \multicolumn{2}{|c|}{ No of unsuccessful interviews } & \multirow[b]{2}{*}{$\mathrm{p}$ Value } \\
\hline & & $\leqslant 3$ & $\geqslant 4$ & \\
\hline First senior house officer post & $\left\{\begin{array}{l}\text { Native European }(n=1363) \\
\text { Ethnic minority }(n=130)\end{array}\right.$ & $\begin{array}{l}91(1247) \\
92(120)\end{array}$ & $\begin{array}{l}9(116) \\
8(10)\end{array}$ & NS \\
\hline Second senior house officer post & $\left\{\begin{array}{l}\text { Native European }(n=1001) \\
\text { Ethnic minority }(n=89)\end{array}\right.$ & $\begin{array}{lr}95 & (947) \\
94 & (84)\end{array}$ & $\begin{array}{lr}5 & (54) \\
6 & (5)\end{array}$ & NS \\
\hline Third senior house officer post & $\left\{\begin{array}{l}\text { Native European }(n=641) \\
\text { Ethnic minority }(n=55)\end{array}\right.$ & $\begin{array}{lr}96 & (615) \\
89 & (49)\end{array}$ & $\begin{array}{rr}4 & (26) \\
11 & (6)\end{array}$ & 0.03 \\
\hline Fourth senior house officer post & $\left\{\begin{array}{l}\text { Native European }(n=458) \\
\text { Ethnic minority }(n=34)\end{array}\right.$ & $\begin{array}{lr}98 & (448) \\
97 & (33)\end{array}$ & $\begin{array}{rr}2 & (10) \\
3 & (1)\end{array}$ & NS \\
\hline Fifth senior house officer post & $\left\{\begin{array}{l}\text { Native European }(n=257) \\
\text { Ethnic minority }(n=20)\end{array}\right.$ & $\begin{array}{rr}99 & (254) \\
85 & (17)\end{array}$ & $\begin{array}{rr}1 & (3) \\
15 & (3)\end{array}$ & $0 \cdot 006$ \\
\hline First registrar post & $\left\{\begin{array}{l}\text { Native European }(n=330) \\
\text { Ethnic minority }(n=20)\end{array}\right.$ & $\begin{array}{lr}95 & (315) \\
95 & (19)\end{array}$ & $\begin{array}{rr}5 & (15) \\
5 & (1)\end{array}$ & NS \\
\hline
\end{tabular}

TABLE $\mathrm{X}$-Percentages of native European and ethnic minority graduates who rated as important and not important seven possible reasons for changing career choice after completing preregistration year. (Whole numbers in parentheses)

\begin{tabular}{|c|c|c|c|}
\hline & Important & Not important & $\mathrm{p}$ Value \\
\hline \multicolumn{4}{|c|}{ Developed interests in another specialty } \\
\hline $\begin{array}{l}\text { Native European }(n=410) \\
\text { Ethnic minority }(n=37)\end{array}$ & $\begin{array}{l}69(284) \\
68(25)\end{array}$ & $\begin{array}{l}31(126) \\
32(12)\end{array}$ & NS \\
\hline \multicolumn{4}{|c|}{ Difficulty in obtaining suitable senior house officer posts } \\
\hline $\begin{array}{l}\text { Native European }(n=410) \\
\text { Ethnic minority }(n=37)\end{array}$ & $\begin{array}{ll}21 & (87) \\
49 & (18)\end{array}$ & $\begin{array}{l}79(323) \\
51(19)\end{array}$ & $<0.001$ \\
\hline \multicolumn{4}{|c|}{ Difficulty in obtaining postgraduate qualifications } \\
\hline $\begin{array}{l}\text { Native European }(n=410) \\
\text { Ethnic minority }(n=37)\end{array}$ & $\begin{array}{rr}20 & (80) \\
24 & (9)\end{array}$ & $\begin{array}{l}80(330) \\
76(28)\end{array}$ & NS \\
\hline \multicolumn{4}{|c|}{ Difficulty in obtaining suitable registrar posts } \\
\hline $\begin{array}{l}\text { Native European }(n=409) \\
\text { Ethnic minority }(n=37)\end{array}$ & $\begin{array}{lr}11 & (46) \\
11 & (4)\end{array}$ & $\begin{array}{l}89(363) \\
89(33)\end{array}$ & NS \\
\hline \multicolumn{4}{|c|}{ Unfavourable career prospects in first specialty } \\
\hline $\begin{array}{l}\text { Native European }(n=410) \\
\text { Ethnic minority }(n=37)\end{array}$ & $\begin{array}{l}56(231) \\
73(27)\end{array}$ & $\begin{array}{l}44(179) \\
27(10)\end{array}$ & $0 \cdot 05$ \\
\hline \multicolumn{4}{|c|}{ Career prospects outside medicine } \\
\hline $\begin{array}{l}\text { Native European }(n=410) \\
\text { Ethnic minority }(n=37)\end{array}$ & $\begin{array}{l}16(64) \\
16 \quad(6)\end{array}$ & $\begin{array}{l}84(346) \\
84(31)\end{array}$ & NS \\
\hline \multicolumn{4}{|c|}{ Domestic or family commitments } \\
\hline $\begin{array}{l}\text { Native European }(n=410) \\
\text { Ethnic minority }(n=37)\end{array}$ & $\begin{array}{l}38(157) \\
32(12)\end{array}$ & $\begin{array}{l}62(253) \\
68(25)\end{array}$ & NS \\
\hline
\end{tabular}

with $441(64 \%)$ of 694 graduates of native European origin $(\mathrm{p}=0.04)$. Thirty seven graduates from ethnic minorities (28\%) and 421 native European graduates $(30 \%)$ had changed their preferred career choice since completing the preregistration year. Of these graduates, $18(49 \%)$ from ethnic minorities compared with 87 of $410(21 \%)$ of native European origin gave difficulty in obtaining senior house officer posts as an important reason (table $\mathrm{X}$ ). Unfavourable career prospects was listed as important by $27(73 \%)$ graduates in the ethnic minority group and $231(56 \%)$ of the native Europeans. Graduates from ethnic minorities were three times more likely than native European graduates to have accumulated more than three months of unemployment while seeking work (table VIII).

\section{Discussion}

In this dataset there was no evidence of discrimination against women in the competition for training posts up to registrar stage. Several women respondents, however, recorded that they had been asked inappropriate questions at interviews - for instance, about their husbands' careers rather than their own. This may understandably have created an impression of unfairness. More serious disadvantage for women may arise from the lack of training structures to accommodate the interruption of careers by childbearing or requirements of part time work.

Among graduates from ethnic minorities there was a striking excess of difficulties related to obtaining training posts. These graduates were no more likely 
than others to choose oversubscribed specialties in which such difficulties would have been expected. It is unlikely that graduates from ethnic minorities were less well qualified than their native European counterparts as there is no evidence that medical school admission policies discriminate in favour of less able applicants from ethnic minorities, and there is considerable evidence that the opposite is the case. ${ }^{137}$ The strength and consistency of the associations found in this study leave little doubt that discrimination against British trained doctors of ethnic minority origin occurs in the competition for training posts.

Most of this discrimination seems to have occurred in the process of shortlisting applicants for senior house officer and registrar posts. Differences between native European and ethnic minority graduates in success rates at interview were much less clear cut. Discrimination at the shortlisting stage may have been based on non-European names, country of birth, and other clues to ethnic origin. The filling of posts by personal arrangement rather than open competition is another possible mechanism of discrimination. Implementing a formal system of grading applicants for senior house officer and registrar posts might help to ensure fair treatment. Monitoring the ethnic mix of doctors appointed in hospitals might also be useful in identifying sites where discrimination may be occurring. We understand that the Department of Health is preparing a draft circular on the implementation of equal opportunities in recruitment and selection procedures for hospital doctors.

We are grateful to the graduates and staff of Manchester, Newcastle, Nottingham, St Mary's, and St Thomas's medical schools for their help with this survey and to Daphne Cottier for coding the completed questionnaires.

1 Smith R. Prejudice against doctors and students from ethnic minorities. BrMed $\mathcal{f}$ 1987;294:328-9.

Lowry S, Macpherson G. A blot on the profession. Br Med f 1988;296:657-8.

3 Collier J, Burke A. Racial and sexual discrimination in the selection of students for London medical schools. Med Educ 1986;20:86-90.

4 Anwar M, Ali A. Overseas doctors: experience and expectations. London: Commission for Racial Equality, 1987.

5 Richards JDM, Richards P. The early postgraduate years: an enquiry by the University Hospitals Association into the progress and career expectations of doctors within six years of graduation. Leeds: University Hospitals Association, 1989.

6 Landis RJ, Heyman ER, Koch GG. Average partial association in three-way contingency tables: a review and discussion of alternative tests. International Statistical Review 1978;46:237-54.

7 McManus IC, Richards P. Admission to medical school. Br Med $\mathcal{F}$ 1985;290: $319-20$.

(Accepted 24 August 1990)

\title{
Serial prothrombin time as prognostic indicator in paracetamol induced fulminant hepatic failure
}

Liver Unit, King's College Hospital and School of Medicine and Dentistry, London SE5 8RX P M Harrison, MRCP, registrar

J G O'Grady, MD, lecturer R T Keays, MRCP, clinical research fellow

G J M Alexander, MRCP, senior lecturer

Roger Williams, FRCP, director

Correspondence to: Dr Williams.

\author{
P M Harrison, J G O’Grady, R T Keays, G J M Alexander, Roger Williams
}

\section{Abstract \\ Objective-To find out whether changes in the daily prothrombin time are of prognostic importance in patients with paracetamol induced fulminant hepatic failure. \\ Design-Retrospective study. \\ Setting - The Liver Unit, King's College Hospital, London. \\ Patients - 150 Consecutive patients with para- cetamol induced fulminant hepatic failure admitted between October 1986 and February 1989. \\ Main outcome measure-Death.}

Results - Of the 150 patients, $72(48 \%)$ died. In all, 34 of the $37(92 \%)$ patients with a peak prothrombin time of $\geqslant 180$ seconds died as did 20 of the $41(49 \%)$ with a time of $130-179$ seconds, nine of the $25(36 \%)$ with a time of 90-129 seconds, and nine of the 47 (19\%) with a time of $<90$ seconds. Of the 42 patients with a continuing rise in prothrombin time between days 3 and 4 after overdose, 39 died (93\%) compared with 21 of the $96(22 \%)$ in whom the prothrombin time fell.

Conclusions - These data indicate that a continued increase in prothrombin time on day 4 after overdose and a peak prothrombin time of $\geqslant 180$ seconds identify at an early stage those patients with a less than $8 \%$ chance of survival. Liver transplantation should be considered in patients meeting either of these criteria.

\section{Introduction}

Survival rates in patients with paracetamol induced fulminant hepatic failure have improved in recent years, probably as a consequence of improvements in intensive liver care, though mortality still remains high (47\% in our unit). ${ }^{1}$ Many variables have been used to assess outcome in these patients, ${ }^{2}$ and coagulation studies have been established as prognostic indicators. ${ }^{3}$ In an early study in our unit factor VII concentration was shown to provide a good indication of prognosis, ${ }^{4}$ and, later use of serial factor VII concentrations were shown to improve the predictive power of this test. ${ }^{5}$ Bernuau et al in Paris, using multivariate analysis, found that a reduced factor $\mathrm{V}$ concentration was the most sensitive prognostic indicator in patients with fulminant hepatitis B infection. ${ }^{6}$ Assay of individual clotting factors is not, however, a routine investigation in most laboratories, whereas measurement of the prothrombin time is reproducible and nearly always available. In a recent analysis of data we showed that a peak prothrombin time of $>100$ seconds provided prognostic information in patients with paracetamol induced fulminant hepatic failure, though supplementary information (that is, serum creatinine concentration and grade of coma) was required to identify patients who had a particularly poor outcome.?

The urgency to define the likely outcome as early as possible after the overdose has been increased by the availability of liver transplantation, which is increasingly utilised in patients with fulminant hepatic failure of other aetiologies. ${ }^{8-12}$ In this study we reviewed a series of 150 consecutive patients with paracetamol induced fulminant hepatic failure to investigate whether changes in the daily prothrombin time complemented the peak prothrombin time in identifying a high risk group who would benefit from liver transplantation.

\section{Patients and methods}

In all, 150 patients with paracetamol induced fulminant hepatic failure were treated in the liver failure unit between October 1986 and February 1989. All of them met the criteria of Trey and Davidson for the diagnosis of fulminant hepatic failure ${ }^{13}$ Most patients 